CZASOPISMO INŻYNIERII LĄDOWEJ, ŚRODOWISKA I ARCHITEKTURY JOURNAL OF CIVIL ENGINEERING, ENVIRONMENT AND ARCHITECTURE

JCEEA, t. XXXIII, z. 63 (3/16), lipiec-wrzesień 2016, s. 579-588

Dominika ZIAJA ${ }^{1}$

Bartosz MILLER ${ }^{2}$

\title{
DETEKCJA USZKODZEŃ NA PRZYKŁADZIE DWUKONDYGNACYJNEJ RAMY PORTALOWEJ Z WYKORZYSTANIEM SZTUCZNYCH SIECI NEURONOWYCH
}

\begin{abstract}
Detekcja uszkodzeń konstrukcji jest jednym z elementów monitorowania stanu konstrukcji, prężnie rozwijającej się dziedziny mającej na celu zwiększenie bezpieczeństwa użytkowania obiektu i minimalizację kosztów jego eksploatacji. W artykule przedstawiono wyniki detekcji uszkodzeń stalowej, dwukondygnacyjnej ramy portalowej z wykorzystaniem analizy parametrów dynamicznych układu (częstotliwości i form drgań). Podstawę rozważań stanowiły dane pomiarowe uzyskane dla różnego rodzaju uszkodzeń węzłów. Dla badanej ramy dokonano analizy zmienności parametrów dynamicznych w zależności od tego, czy uszkodzenie węzła wystąpiło czy nie. Jako narzędzie umożliwiające klasyfikację wzorców zastosowano jednowarstwowe, jednokierunkowe sieci neuronowe. W opracowaniu zaprezentowano wyniki dla sieci neuronowych o różnej architekturze oraz przy zróżnicowanym podziale na zbiory uczące i testujące.
\end{abstract}

Słowa kluczowe: monitorowanie stanu konstrukcji (SHM), sztuczne sieci neuronowe

\section{Wprowadzenie}

Monitorowanie stanu konstrukcji znajduje obecnie coraz szersze zastosowanie nie tylko $\mathrm{w}$ przemyśle lotniczym, motoryzacyjnym ale również $\mathrm{w}$ budownictwie. Nie trzeba z pewnością nikogo przekonywać o korzyściach płynących z wczesnej detekcji uszkodzeń, a co za tym idzie możliwości zapobiegania poważnym awariom i katastrofom budowlanym.

Wciąż rosnące możliwości techniczne powodują rozwój różnorodnych technik pomiarowych wykorzystywanych $\mathrm{w}$ monitorowaniu stanu konstrukcji.

\footnotetext{
${ }^{1}$ Autor do korespondencji / corresponding author: Dominika Ziaja, Politechnika Rzeszowska, al. Powstańców Warszawy 12, 35-959 Rzeszów, tel. (0-17)8651618, dziaja@prz.edu.pl

${ }^{2}$ Bartosz Miller, Politechnika Rzeszowska, al. Powstańców Warszawy 12, 35-959 Rzeszów, tel.(0-17)8651532, bartosz.miller@prz.edu.pl
} 
Szczególnie popularne stają się techniki nieniszczące, gdyż umożliwiają nieprzerwaną eksploatację obiektu zarówno w trakcie badań, jak i po ich zakończeniu. Jedną z nieniszczących technik pomiarowych, wykorzystaną w prezentowanych badaniach, jest pomiar przyspieszeń będących odpowiedzią na wymuszenie dynamiczne w wybranych punktach układu. Zgromadzone w ten sposób dane wykorzystywane są do wykonania analizy modalnej w celu określenia parametrów dynamicznych konstrukcji takich jak: częstotliwości i postaci drgań oraz współczynniki tłumienia [1]. Porównanie parametrów dynamicznych konstrukcji w chwili przeprowadzenia pomiaru z parametrami odpowiadającymi konstrukcji w stanie nieuszkodzonym pozwala ocenić, czy w układzie nastąpiły zmiany i czy są one dla obiektu niebezpieczne [2].

$\mathrm{W}$ artykule przedstawiono wyniki badań mających na celu określenie stanu konstrukcji i zaklasyfikowanie jej jako uszkodzona bądź nieuszkodzona, na przykładzie dwukondygnacyjnej, stalowej ramy portalowej. Prezentowane wyniki bazują na danych doświadczalnych, a analizę zmian parametrów dynamicznych wykonano przy użyciu sztucznych sieci neuronowych [3-4].

\section{Opis modelu}

Rys. 1 przedstawia schemat modelu laboratoryjnego dwukondygnacyjnej ramy portalowej. Zarówno słupy jak i rygle wykonano z kształtownika IPE80. Połączenia rygiel-słup wykonano jako doczołowe, posiadające zgodnie z Rys. 2. cztery rzędy śrub M8 klasy 8.8.

W trakcie badań drgania modelu wymuszano używając zamocowanego na dodatkowej konstrukcji wsporczej wzbudnika firmy The Modal Shop, Inc. Model $2100 \mathrm{E} 11$, a biały szum w zakresie $0-256 \mathrm{~Hz}$ wygenerowany został przez pakiet LMS TestLab. Zarówno kierunek wymuszenia, jak i kierunki pomiaru przyspieszeń znajdowały się w płaszczyźnie ramy. Przyspieszenia mierzono przy użyciu 12 jednoosiowych czujników PCB Piezotronics, Inc. Model 352C03, z których każdy zamocowano w innym punkcie pomiarowym. Siłę wymuszającą rejestrowano za pomocą czujnika PCB Piezotronics, Inc. Model 208C03. Rozmieszczenie czujników pokazano na Rys. 1. W trakcie pomiarów wykorzystano analizator LMS SCADAS Mobile. Parametry pomiaru dobrano tak, aby pomierzony sygnał po transformacji do dziedziny częstotliwości miał zakres $0-256 \mathrm{~Hz}$ i rozdzielczość $0.125 \mathrm{~Hz}$, a analizę modalną przeprowadzono przy użyciu procedury Polymax dostępnej w komercyjnym pakiecie LMS Testlab Spectral Testing [5].

Plan badań zakładał wykonanie pomiarów zarówno układu nieuszkodzonego, jak i układów z uszkodzeniami połączenia rygiel - słup. Uszkodzenie polegało na rozkręceniu jednego, dwóch lub trzech rzędów śrub w różnej konfiguracji, dla każdego połączenia tego typu. W trakcie pojedynczego pomiaru uszkodzony był tylko jeden węzeł. Podczas pomiarów przeprowadzano kilkukrotnie kontrolne badania ramy bez uszkodzeń. W ten sposób zgromadzono 88 wzorców w tym 65 dla ramy z uszkodzeniem i 23 dla ramy bez uszkodzenia. 


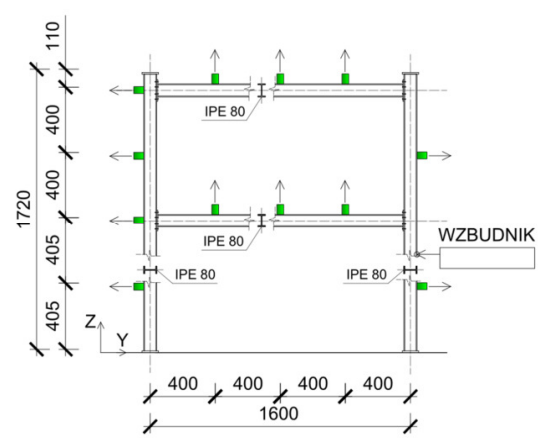

Rys. 1. Schemat modelu fizycznego wraz z rozmieszczeniem czujników i kierunkami pomiarowymi, wymiary $\mathrm{w} \mathrm{mm}$

Fig. 1. Physical model and localization of accelerometers, dimensions in $\mathrm{mm}$
$1-1$

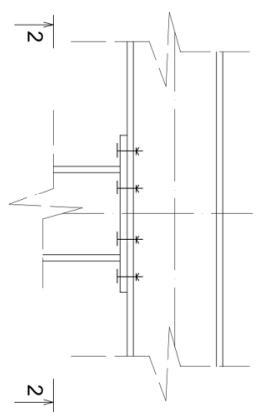

$2-2$

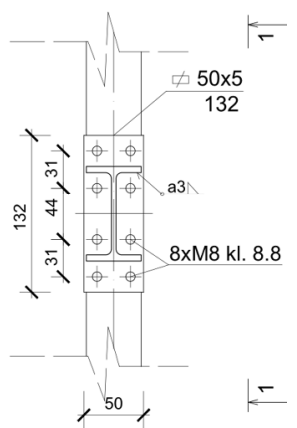

Rys. 2. Połączenie rygiel-słup, wymiary w mm

Fig. 2. Beam-to-column connection, dimensions in $\mathrm{mm}$

\section{Detekcja uszkodzeń}

\subsection{Analiza danych pomiarowych}

Pierwszym etapem była analiza wartości częstotliwości drgań otrzymanych z pomiarów. Dla wzorców uszkodzonych i nieuszkodzonych wyznaczono oddzielnie średnie wartości częstotliwości, przy czym, jeśli w danym pomiarze nie zaobserwowano odpowiedniej częstotliwości modalnej pomiar nie był brany pod uwagę podczas wyznaczania wartości średniej. Odrzucono również maksymalną i minimalną wartość pomiaru dla odpowiedniej częstotliwości. Przykładowo pierwsze i dziewiąte częstotliwości drgań oraz wyznaczone wartości średnie przedstawiono na Rys. 3.

Tabela 1 pokazuje wartości średnie uzyskane podczas pomiarów dla wszystkich analizowanych częstotliwości, zarówno dla wzorców uszkodzonych jak i nieuszkodzonych, a także zakresy zmienności wykorzystane do zaszumiania danych w późniejszym etapie. Średnie wartości częstotliwości dla ramy uszkodzonej i nieuszkodzonej wyraźnie się różnią. Niestety odchylenia poszczególnych pomiarów od wartości średniej są duże (patrz Rys. 3), co utrudnia odpowiednią klasyfikację wzorców. Dlatego też do przeprowadzenia klasyfikacji wzorców wykorzystano sztuczne sieci neuronowe. 

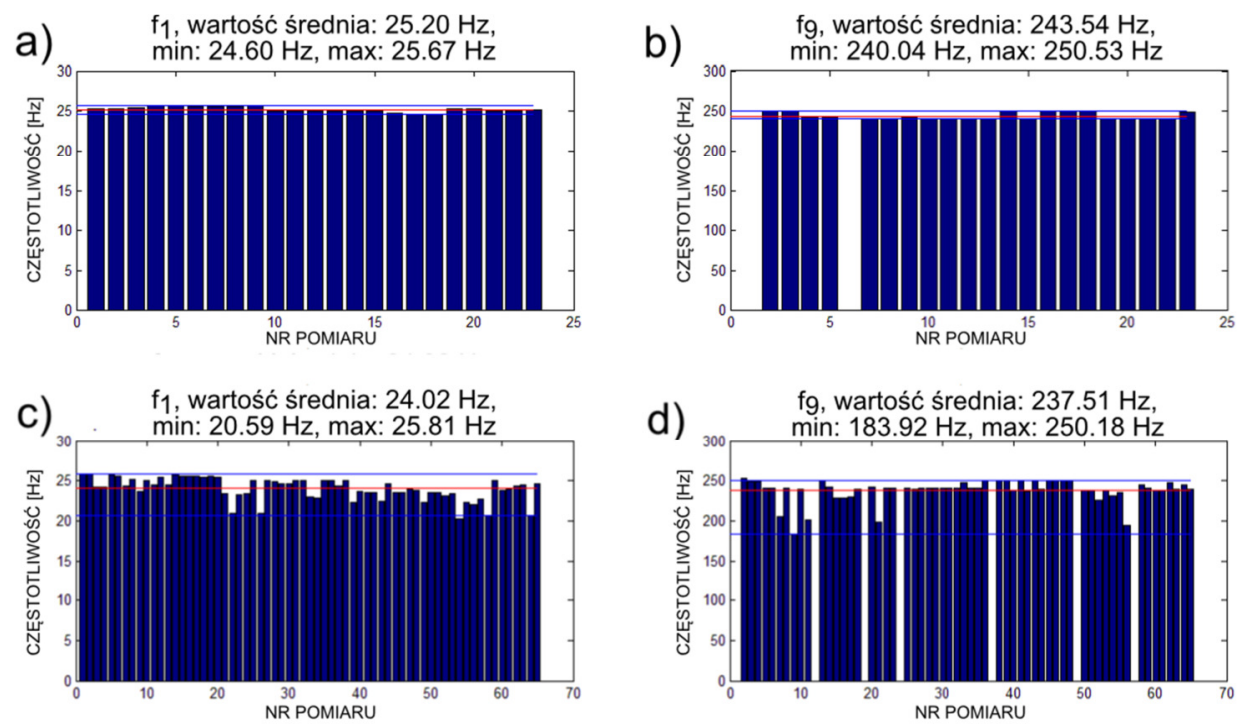

Rys. 3. Porównanie wyników pomiarów oraz wartości średnie dla pierwszej i dziewiątej częstotliwości drgań dla a) i b) ramy bez uszkodzenia, c) i d) ramy uszkodzonej

Fig. 3. Comparison of the measurement results and the average values for the first and ninth modal frequency for a) and b) the frame without damage, c) and d) the frame corrupted

Tabela 1. Analiza zmian częstotliwości

Table 1. Analysis of changes in frequency

\begin{tabular}{|c|c|r|c|r|}
\hline \multirow{2}{*}{$\begin{array}{c}\mathbf{n r} \\
\text { Częst. }\end{array}$} & \multicolumn{2}{|c|}{ Rama bez uszkodzenia } & \multicolumn{2}{c|}{ Rama z uszkodzeniem } \\
\cline { 2 - 6 } & $\begin{array}{c}\mathbf{f}_{\text {srednia }} \\
{[\mathbf{H z}]}\end{array}$ & $\begin{array}{c}\text { zakres } \\
\text { do zaszumiania } \\
{[\mathbf{H z}]}\end{array}$ & $\begin{array}{c}\mathbf{f}_{\text {srednia }} \\
{[\mathrm{Hz}]}\end{array}$ & $\begin{array}{c}\text { zakres } \\
\text { do zaszumiania } \\
{[\mathrm{Hz}]}\end{array}$ \\
\hline 1 & 25.20 & $25.20 \pm 0.47$ & 24.02 & $24.02 \pm 1.79$ \\
\hline 2 & 110.01 & $110.01 \pm 2.97$ & 107.90 & $107.90 \pm 5.11$ \\
\hline 3 & 116.68 & $116.68 \pm 12.43$ & 120.93 & $120.93 \pm 11.38$ \\
\hline 4 & 133.46 & $133.46 \pm 9.93$ & 136.91 & $136.91 \pm 10.27$ \\
\hline 5 & 147.35 & $147.35 \pm 7.74$ & 147.67 & $147.67 \pm 12.93$ \\
\hline 6 & 156.16 & $156.16 \pm 4.56$ & 164.71 & $164.71 \pm 21.90$ \\
\hline 7 & 176.11 & $176.11 \pm 28.62$ & 187.04 & $187.04 \pm 38.83$ \\
\hline 8 & 216.58 & $216.58 \pm 24.64$ & 216.58 & $216.58 \pm 33.97$ \\
\hline 9 & 243.54 & $243.54 \pm 7.00$ & 237.51 & $237.51 \pm 12.67$ \\
\hline 10 & 249.94 & $249.94 \pm 0.99$ & 245.08 & $245.08 \pm 6.54$ \\
\hline
\end{tabular}

\subsection{Detekcja uszkodzeń z wykorzystaniem sztucznych sieci neuronowych w oparciu o częstotliwości drgań}

W celu określenia czy dany wzorzec odpowiada ramie uszkodzonej czy nie zastosowano jednowarstwowe, jednokierunkowe sztuczne sieci neuronowe. Do uczenia sieci wykorzystano algorytm Levenberga-Marquardta [6]. Początkowo uczono sieci o różnej liczbie neuronów wejściowych i różnej liczbie neuronów 
w warstwie ukrytej. Danymi wejściowymi każdorazowo były kolejne częstotliwości drgań (od pierwszych czterech do dziesięciu), a liczba neuronów w warstwie ukrytej zmieniała się od 1 do 14 tak, aby liczba parametrów sieci nie przekraczała liczby wzorców uczących. We wszystkich sieciach występował tylko jeden neuron wyjściowy, określający czy rama została uszkodzona czy nie.

W pierwszym kroku uczono i testowano działanie sieci na wszystkich dostępnych wzorcach. Rys. 4 i 5. przedstawiają najlepsze wyniki otrzymane dla sieci bazującej na czterech pierwszych częstościach (o architekturze 4-12-1) i wszystkich dziesięciu częstotliwościach (architektura 10-5-1). W każdym z prezentowanych przypadków wzorce błędnie zakwalifikowane stanowiły odpowiednio $17 \%$ i $16 \%$.

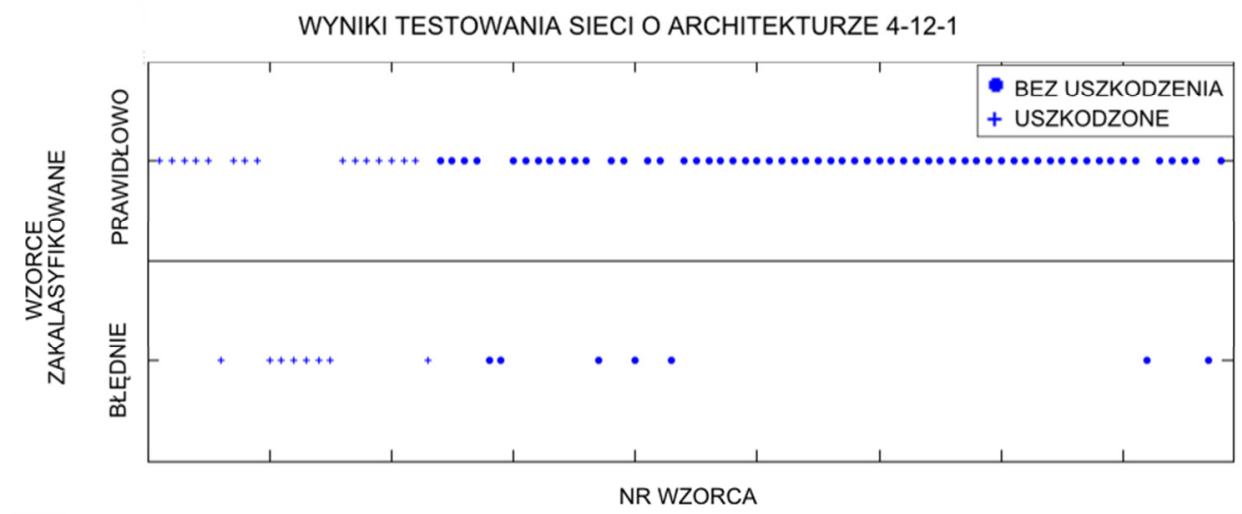

Rys. 4. Wyniki testowania sieci o architekturze 4-12-1, uczenie i testowanie na pełnym zbiorze wzorców

Fig. 4. Testing results of artificial neural network with architecture 4-12-1, learning and testing with using full set of patterns

Niezadowalające rezultaty otrzymane z pierwszej próby mogły być wynikiem zbyt małej liczby wzorców otrzymanych z pomiarów, dlatego też postanowiono wygenerować dodatkowe wzorce służące wyłącznie uczeniu sieci. Na podstawie pomierzonych częstotliwości wygenerowano dziesięciokrotnie więcej wzorców zaszumionych dla ramy bez uszkodzenia (230 wzorców) i pięciokrotnie więcej wzorców dla ramy uszkodzonej (325 wzorców) (dla zwiększenia udziału wzorców bez uszkodzenia w ogólnej puli wzorców uczących). Analiza zmian wartości częstotliwości pozwoliła na określenie przedziałów przedstawionych w Tabeli 1. Zaszumienie danych wykonano poprzez losowy wybór wartości częstotliwości z odpowiedniego przedziału zmienności. Oryginalne wzorce nie były używane do uczenia. Testowanie sieci odbywało się nadal na pełnym zbiorze 88 wzorców z pomiarów. Rys. 6. przedstawia wyniki testowania dla sieci uczonej na wzorcach zaszumionych. Niestety proces sztucznego zwiększenia liczby wzorców nie poprawił rezultatów otrzymanych poprzednio, gdyż udział 


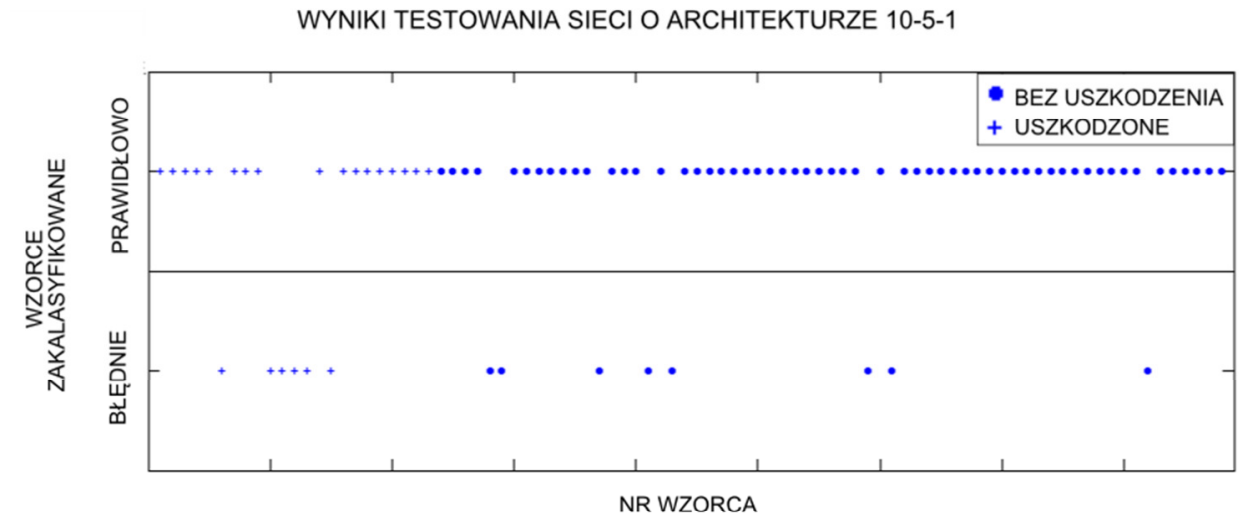

Rys. 5. Wyniki testowania sieci o architekturze 10-5-1, uczenie i testowanie na pełnym zbiorze wzorców

Fig. 5. Testing results of artificial neural network with architecture 10-5-1, learning and testing with using full set of patterns

wzorców błędnie zaklasyfikowanych nadal pozostał na poziomie $17 \%$. Jedyna korzyść takiego postępowania polega na bardziej obiektywnym testowaniu sieci, ponieważ wzorce użyte do testowania nie były uprzednio wykorzystane do uczenia.

Ponieważ zaszumianie danych nie poprawiło znacząco wyników testowania sieci powrócono do wzorców bez zaszumienia. Zbiór podzielono w stosunku 3:1 na zbiór uczący (66 wzorców) oraz testujący ( 22 wzorce). Wzorce wybierano

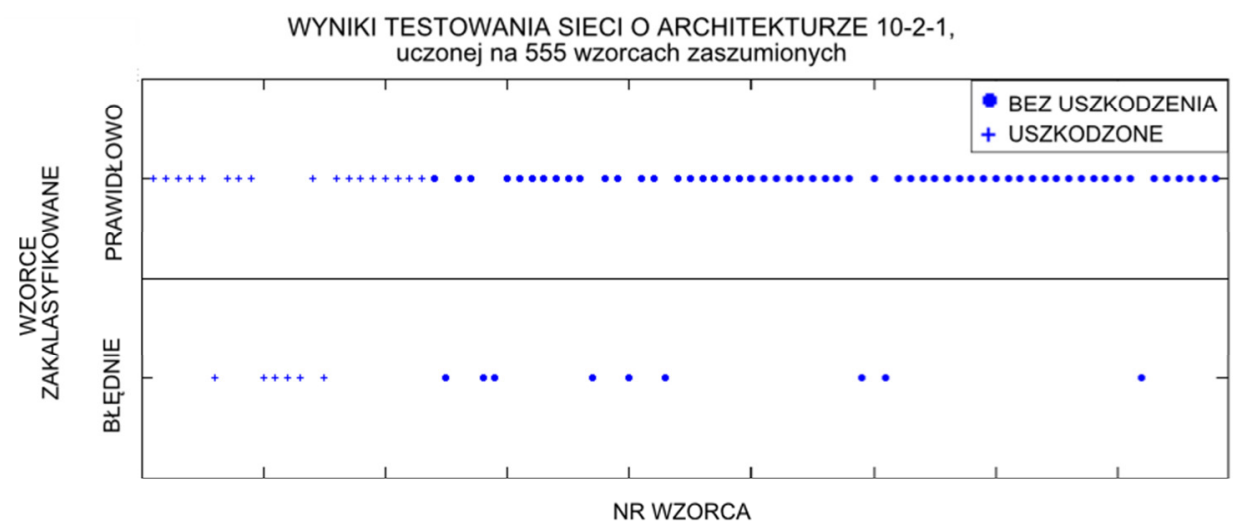

Rys. 6. Wyniki testowania sieci o architekturze 10-2-1, uczenie na wzorcach zaszumionych, testowanie na wzorcach z pomiarów

Fig. 6. Testing results of artificial neural network with architecture 10-2-1, learning with set of noisy patterns, testing with using full set of measurement patterns 
w sposób losowy. Uczono i testowano sieci o 10 neuronach wejściowych (odpowiadających 10 częstotliwościom drgań) oraz zmiennej liczbie neuronów w warstwie ukrytej. Najlepsze wyniki dla jednego z podziałów przedstawiono na Rys. 7 i 8 . Błędnie zaklasyfikowane wzorce stanowiły $14 \%$ wzorców testujących i $16 \%$ wszystkich wzorców.

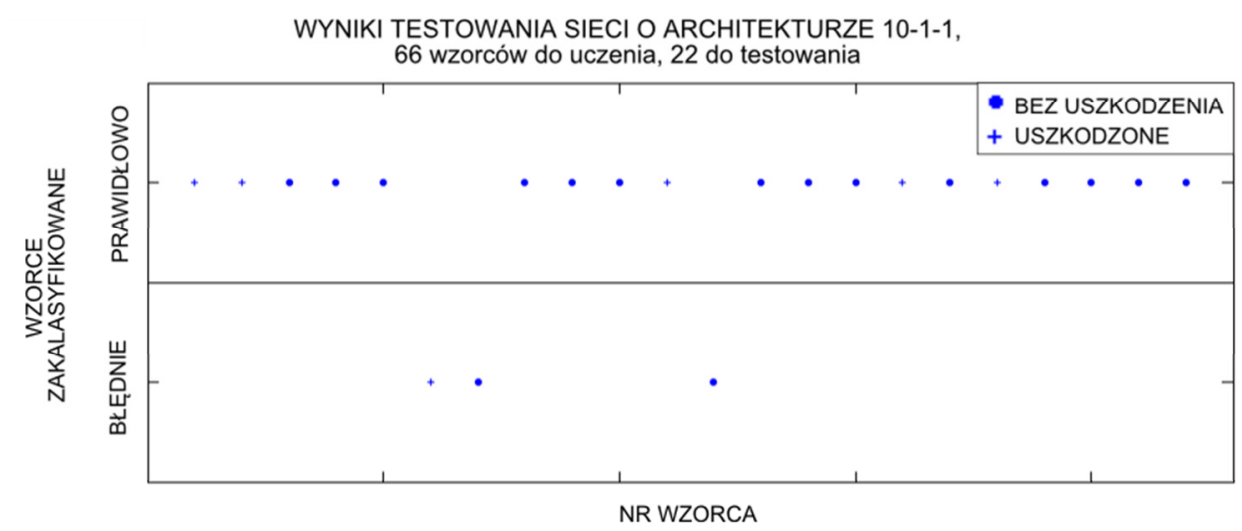

Rys. 7. Wyniki testowania sieci o architekturze 10-1-1, 75\%wzorców uczących i 25\% wzorców testujących

Fig. 7. Testing results of artificial neural network with architecture 10-1-1, learning: $75 \%$ of patterns, testing: $25 \%$ of patterns

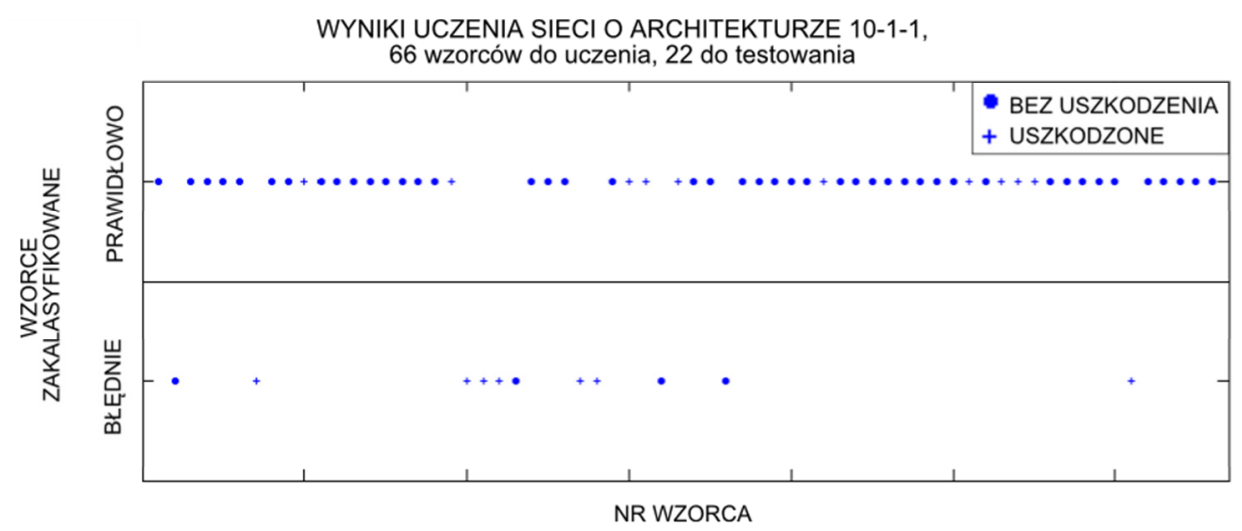

Rys. 8. Wyniki uczenia sieci o architekturze 10-1-1, 75\%wzorców uczących i 25\% wzorców testujących

Fig. 8. Learning results of artificial neural network with architecture $10-1-1$, learning: $75 \%$ of patterns, testing: $25 \%$ of patterns 


\subsection{Detekcja uszkodzeń na podstawie częstotliwości i form}

Kolejną próbą poprawienia wyników działania sieci było wykorzystanie informacji o postaci drgań. W trakcie pomiarów wyznaczono formy drgań odpowiadające każdej częstotliwości. Każdą formę opisywał wektor składający się z 12 wartości przemieszczeń w punktach pomiarowych. Formy znormalizowano, jednak ze względu na dużą ilość danych (dla każdej sytuacji pomiarowej informacja o dziesięciu postaciach drgań składała się ze 120 wartości) zastosowano analizę składników głównych (Principal Component Analysis, PCA), a następnie otrzymane w jej wyniku składniki główne w ilości pierwszych dwóch do pięciu stanowiły dodatkową informację dla sieci neuronowych. Uczenie i testowanie odbywało się na wzorcach oryginalnych (bez zaszumienia), które podzielono w sposób losowy w stosunku 3:1 (75\% wzorców do uczenia i 25\% do testowania). Analizowano sieci o różnej architekturze, przy zmiennej liczbie parametrów wejściowych, z których pierwsze pięć do dziesięciu odpowiadało kolejnym częstotliwościom, a następne dwa do pięciu składnikom głównym z form. Liczbę neuronów w warstwie ukrytej ograniczono tak, aby liczba wzorców uczących nie była mniejsza od liczby parametrów sieci. Najlepszy wynik dla podziału na zbiory jak w punkcie 3.1 otrzymano dla 5 częstotliwości i 5 składników głównych, gdzie wzorce błędnie zaklasyfikowane stanowiły 14\% wzorców testujących (Rys. 9) oraz 15\% wszystkich wzorców (łącznie, w tym: dla uczenia (Rys. 10) i testowania (Rys. 9)).

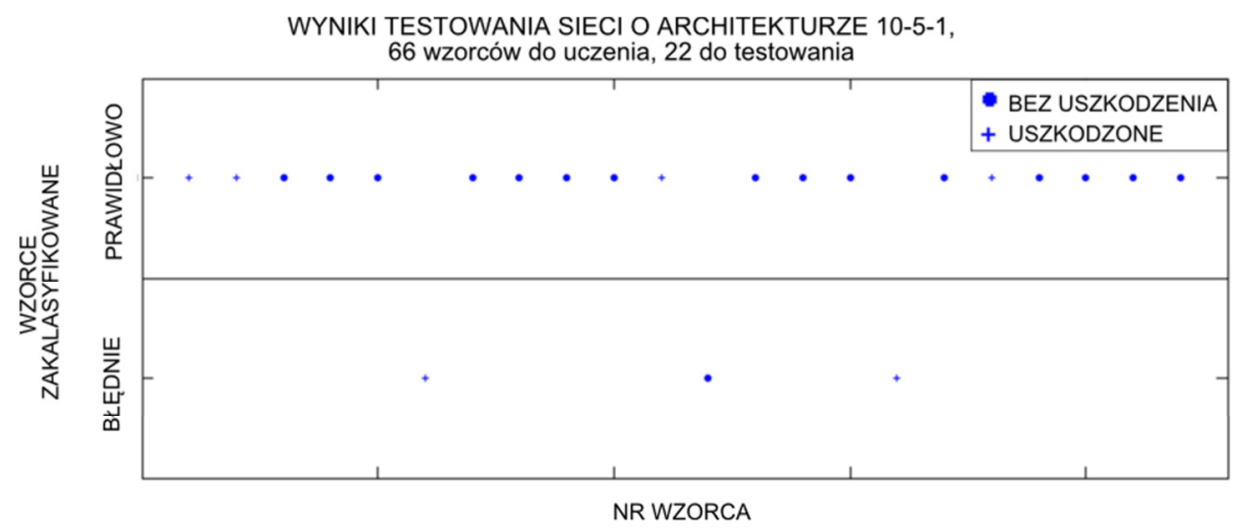

Rys. 9. Wyniki testowania sieci o architekturze 10-5-1, na wejściu 5 częstotliwości i 5 składników głównych z form

Fig. 9. Testing results of artificial neural network with architecture 10-5-1, input: 5 modal frequencies and 5 principal components 


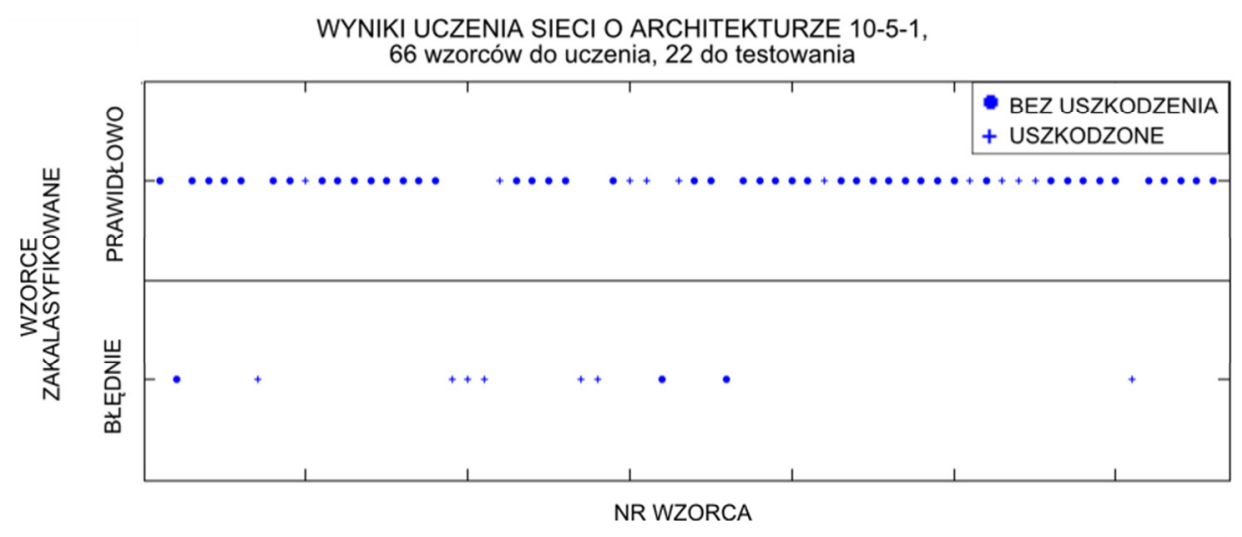

Rys. 10. Wyniki uczenia sieci o architekturze 10-5-1, na wejściu 5 częstotliwości i 5 składników głównych $\mathrm{z}$ form

Fig. 10. Learning results of artificial neural network with architecture 10-5-1, input: 5 modal frequencies and 5 principal components

\section{Wnioski}

Sztuczne sieci neuronowe mogą być wykorzystane do klasyfikacji wzorców. Otrzymane rezultaty pozwalają na poziomie $83 \%$ - 85\% poprawnie określić, czy dana konstrukcja została uszkodzona czy nie i stanowią punkt wyjścia dla poszukiwania lepszych rozwiązań. Trwają prace nad oceną możliwości poprawy wyników dzięki zastosowaniu sieci innego rodzaju niż prezentowane w artykule. Jednocześnie, ze względu na znaczne rozbieżności wyników pomiarów, sprawdzenia wymagają również dane pomiarowe. Planowane jest ponowne wykonanie badań modelu fizycznego.

\section{Podziękowania}

Program MATLAB wykorzystany do przeprowadzenia badań został zakupiony w wyniku realizacji Projektu nr UDA-RPPK.01.03.00-18-003/10-00 „Budowa, rozbudowa i modernizacja bazy naukowo-badawczej Politechniki Rzeszowskiej” współfinansowanego ze środków Unii Europejskiej w ramach Regionalnego Programu Operacyjnego Województwa Podkarpackiego na lata 2007-2013, Priorytet I. Konkurencyjna i Innowacyjna Gospodarka, Działanie 1.3 Regionalny system innowacji.

Do badań wykorzystano aparaturę zakupioną w projekcie nr POPW.01.03.00-18012/09 z Funduszy Strukturalnych w ramach Programu Operacyjnego Rozwój Polski Wschodniej współfinansowanego przez Unię Europejską ze środków Europejskiego Funduszu Rozwoju Regionalnego. 


\section{Literatura}

[1] Lewandowski R.:, Dynamika konstrukcji budowlanych, Politechnika Poznańska, Poznań 2006.

[2] Wilde K.: Modal Diagnostics Of Civil Engineering Structures, Gdańsk University Of Technology Publishers, Gdańsk 2008.

[3] Waszczyszyn Z.: Artificial neural networks in civil engineering: another five years of research in Poland, Computer Assisted Mechanics and Engineering Sciences, nr 18, 2011, s. 131-146.

[4] Nazarko P., Ziemiański L.: Application of artificial neural networks in the damage identification of structural elements, Computer Assisted Mechanics and Engineering Sciences, nr 18, 2011, s. 175-189.

[5] LMS Test.Lab, The LMS Test.Lab Spectral Testing manual, LMS International 2009.

[6] Haykin S.: Neural Networks: a Comprehensive Foundation, Prentice Hall International, Inc., $2^{\text {nd }}$ ed., 1999.

\section{DAMAGE DETECTION ON THE EXAMPLE OF TWO-STOREY PORTAL FRAME WITH USING ARTIFICIAL NEURAL NETWORK}

\section{S u m m a r y}

Detection of structural damage is one of the elements of structural health monitoring, a rapidly developing area aimed at improving the reliability and minimize the construction maintenance costs. The article presents the results of damage detection of a steel, two-storey portal frame using dynamic parameters analysis (modal frequencies and forms). Considerations, based on the measurement data, were obtained for various kinds of beam-to-column connection failure. As a tool for classification feed-forward backpropagation neural networks with one hidden layer were used. The paper presents the results obtained from neural networks of various architectures and with varying division into learning and testing data sets.

Keywords: structural health monitoring (SHM), artificial neural networks

DOI:10.7862/rb.2016.242

Przestano do redakcji: 17.08.2016 r.

Przyjęto do druku: 30.11.2016 r. 